\title{
In Vivo Expression of Neutrophil Inhibitory Factor via Gene Transfer Prevents Lipopolysaccharide-induced Lung Neutrophil Infiltration and Injury by a $\beta_{2}$ Integrin-dependent Mechanism
}

\author{
Ming-Yuan Zhou, ${ }^{\star}$ Siu K. Lo, ${ }^{\S}$ Magnus Bergenfeldt, ${ }^{*}$ Chinnaswamy Tiruppathi, ${ }^{\text {Ari }}$ Jaffe, ${ }^{\ddagger}$ Ning Xu, ${ }^{\star}$ and Asrar B. Malik ${ }^{\star}$ \\ ${ }^{*}$ Department of Pharmacology and ${ }^{\ddagger}$ Department of Medicine, College of Medicine, The University of Illinois, Chicago, Illinois 60612; and \\ Department of Medicine, ${ }^{\S}$ Division of Hematology and Oncology, Cornell University Medical College, New York 10021
}

\section{Abstract}

The binding of $\beta_{2}$ (CD18) integrins on PMN cell membrane to intercellular adhesion molecule (ICAM) counter-receptors on the surface of vascular endothelial cells mediates PMN adhesion to endothelial cells. Neutrophil inhibitory factor (NIF), a 41-kD glycoprotein isolated from the canine hookworm (Ancylostoma caninum), is a $\beta_{2}$ integrin antagonist that inhibits PMN adhesion to endothelial cells. We transferred the NIF gene into CD1 mouse lungs by intravenous injection of cationic liposomes to study the effects of in vivo NIF expression on LPS-induced lung PMN sequestration and the development of lung injury. RT-PCR and Northern blot analysis indicated the lung-selective expression of the NIF transgene, and immunocytochemistry showed prominent NIF expression in pulmonary microvessel endothelial cells. NIF staining was also observed in intraluminal leukocytes present in pulmonary microvessels. This may be the result of NIF binding to leukocytes after its secretion from the transduced lung cells, since there was no evidence of NIF gene expression in circulating leukocytes. Pulmonary vascular NIF expression abrogated the lung tissue PMN uptake and airspace migration of PMN and prevented lung vascular injury (as measured by the lung tissue uptake of $\left[{ }^{125} \mathrm{I}\right]$ labeled albumin) after the intraperitoneal LPS challenge ( $200 \mu \mathrm{g} / \mathrm{mouse})$. Expression of a control protein, chloramphenicol acetyltransferase (CAT), by the same strategy, had no effect on these responses. In vitro studies showed that NIF prevented mouse PMN adhesion consistent with the inhibition of lung uptake after LPS challenge in NIF transgene-expressing mice. We conclude that pulmonary vascular expression of NIF, a specific $\beta_{2}$ integrinbinding protein, is a potentially useful gene transfer strategy in modulating the infiltration of PMN across the alveolarcapillary epithelial barrier and in preventing lung vascular endothelial injury. (J. Clin. Invest. 1998. 101:2427-2437.) Key words: liposome-mediated gene transfer • CD11a - CD11b • CD18 • intercellular adhesion molecules

Address correspondence to Asrar B. Malik, Department of Pharmacology, University of Illinois College of Medicine, $835 \mathrm{~S}$. Wolcott Ave. (m/c 868), Chicago, IL 60612. Phone: 312-996-7635; FAX: 312996-1225; E-mail: abmalik@uic.edu

Received for publication 15 April 1997 and accepted in revised form 17 March 1998.

J. Clin. Invest.

(C) The American Society for Clinical Investigation, Inc. 0021-9738/98/06/2427/11 \$2.00

Volume 101, Number 11, June 1998, 2427-2437

http://www.jci.org

\section{Introduction}

Gram-negative sepsis is the most common cause of the adult respiratory distress syndrome, which is characterized by sequestration of PMNs in the pulmonary microcirculation and their migration into the alveolar space (1). LPS, a component of the wall of gram-negative bacteria, administered in vivo produces several pathophysiological changes characteristic of adult respiratory distress syndrome (1). Lung injury develops as the result of release of proteases and reactive oxygen species from PMNs adherent to pulmonary microvessel endothelial cells and infiltration of PMN into airspaces $(2,3)$.

The binding of CD11/CD18 or the $\beta_{2}$ family of integrins on PMN to the intercellular adhesion molecule (ICAM) $)^{1}-1$ and ICAM-2 counter-receptors (3-5) expressed on the endothelial cell surface stabilizes PMN adhesion, and promotes PMN migration across the vessel wall after LPS exposure $(3,4)$. The $\beta_{2}$ integrins CD11a/CD18 and CD11b/CD18 are heterodimeric leukocyte surface receptors formed by the variant CD11 subunits and the common CD18 subunit (6-8). Expression of CD11a/CD18 and CD11b/CD18 integrins in response to proinflammatory cytokines and LPS contributes to leukocyte adhesion to the endothelium and both integrin family members mediate the adhesion-dependent degranulation and respiratory burst responses of PMN and coordinate their transendothelial migration (5, 9-11). Although CD11a/CD18 and CD11b/CD18 bind to several ligands, they bind specifically to ICAM-1 (CD54) and ICAM-2 (CD102) expressed on the endothelial cell surface $(4,12-15)$. It has been proposed that adhesiondependent activation of PMN signaled by the interaction of $\beta_{2}$ integrins with ICAMs is a critical event regulating the emigration of PMNs across the vascular endothelial barrier $(3,4,13)$.

Studies have shown protective effects of both anti-CD11/ CD18 and anti-ICAM-1 mAbs in models of acute lung injury (including that induced by septicemia) $(5,16,17)$. Protection in these models has been universally attributed to inhibition of PMN sequestration in the lungs $(5,16,17)$. However, the results using mAbs have not always agreed with experiments in mice made genetically deficient in adhesion molecules $(5,18$ 20). This may be the result of upregulation of compensatory pathways in response to the long-term loss of CD18 integrins or ICAM-1 in these knockout mouse models and to the potential nonspecific actions of $\mathrm{mAbs}$, such as their ability to induce leukocytosis (21).

Neutrophil inhibitory factor (NIF), a glycosylated 41-kD protein isolated from canine hookworm (Ancylostoma cani-

1. Abbreviations used in this paper: $\mathrm{BAL}$, bronchoalveolar lavage; CAT, chloramphenicol acetyltransferase; i.p., intraperitoneal(ly); i.t., intratracheal(ly); i.v., intravenous(ly); ICAM, intercellular adhesion molecule; MPO, myeloperoxidase; NIF, neutrophil inhibitory factor; rNIF, recombinant NIF protein; RT, reverse transcriptase. 
num), inhibits PMN spreading and adhesion to endothelial cells (22). NIF binds with high affinity to the metal ion-dependent adhesion site on the A domain of the CD11b subunit of PMN (22-24) and inhibits formyl methionyl leucyl phenylalanine (FMLP)-dependent adhesion of PMN to ICAM-1 and the release of $\mathrm{H}_{2} \mathrm{O}_{2}$ by PMN $(14,22)$. We have shown that NIF can also bind to CD11a expressed on activated PMN (Malik, A.B., and S.K. Lo, unpublished observation). In addition, we showed that infusion of recombinant NIF protein (rNIF) prevented lung PMN uptake and PMN-dependent lung injury induced by TNF- $\alpha$ challenge of guinea pigs (25). Since the in vivo expression of NIF may be a useful gene transfer strategy in modulating or reversing lung PMN sequestration and the trafficking of PMN into the airspace, in this study, we transferred the NIF gene into mouse pulmonary microvessel endothelial cells using cationic liposomes and determined the effects of NIF expression on LPS-induced pulmonary PMN sequestration and airspace migration of PMN, and on the development of lung vascular injury.

\section{Methods}

Mice. Pathogen-free CD1 mice (6-12-wk-old males, 25-30 g body wt) (Harlan Co., Indianapolis, IN) were used in all experiments. Mice were housed in pathogen-free conditions in The University of Illinois Animal Care Facility where they were treated in accordance with institutional and National Institutes of Health guidelines. Before injection of transgene/liposome constructs, the mice were anesthetized with an intramuscular injection of ketamine $(60 \mathrm{mg} / \mathrm{kg})$ and xylazine $(2 \mathrm{mg} / \mathrm{kg})$ in PBS. Mice were studied at $2 \mathrm{~d}$ for analysis of transgene expression and for challenge with LPS as described below.

Transgene construction. The eukaryotic expression vector, pCR3 (Invitrogen, San Diego, CA), which contains the cytomegalovirus (CMV) promoter, bovine growth hormone polyadenylation signal, and transcription termination signal was used as the cloning vector. The reporter cDNAs, chloramphenicol acetyltransferase (CAT), and Escherichia coli Lac $Z$ ( $\beta$-galactosidase) were separately cloned into the HindIII site in pCR3 to generate reporter gene constructs. NIF cDNA from pBluescript $\mathrm{SK}^{+}$(provided by Drs. Matthew Moyle and Howard Soule; Corvas, La Jolla, CA) was cloned into the EcoR1 site in pCR3 to generate the pCR3-NIF construct. All constructs were verified by restriction mapping and DNA sequencing using Sequenase version 2.0 (Amersham, Arlington Heights, IL). In vitro transfection was successfully performed using pCR3-ßgal and pCR3-NIF constructs transfected into 293 cells (human embryonic kidney cells from the American Type Culture Collection, Rockville, MD) to demonstrate in vitro effectiveness of transgene expression (data not shown).

DNA/liposome constructs and in vivo gene transfer. Dimethyldioctadecylammonium bromide (DDAB; Sigma Chemical Co., St. Louis, MO) and cholesterol (Calbiochem Co., La Jolla, CA) in chloroform were used to prepare liposomes as described previously (26, 27). Briefly, the mixture consisting of dimethyldioctadecylammonium bromide and cholesterol (1:1 molar ratio) was dried using the Rotavaporator (Brinkmann, Westbury, NY) and dissolved in $5 \%$ glucose. The lipid molecules were sonicated for $20 \mathrm{~min}$. The complex consisting of the transgene (50 $\mu \mathrm{g}$ per mouse) and liposomes was combined at the ratio of $1 \mu \mathrm{g}$ of DNA to $8 \mathrm{nmol}$ of liposomes. The DNA/liposome construct was intravenously (i.v.) injected in CD1 mice. For the CAT activity analysis, protein was extracted from different organs and CAT activity was assayed using an equivalent amount of protein from tissue extracts and quantified as described previously (28).

Reverse transcriptase $(R T)-P C R$. RT-PCR was performed with the SuperScript Preamplification Reagent System (Life Technologies, Gaithersburg, MD). Lung or leukocyte RNA samples were pre- treated with RNase-free DNase I to eliminate DNA contamination. Samples were mixed with oligo(dT) primers and RT and incubated at $42^{\circ} \mathrm{C}$ for $1 \mathrm{~h}$ for cDNA synthesis. PCR was carried out after addition of $0.5 \mathrm{nM}$ of primers (i.e., 5'-ACACAACCTGAGGTGC-3' and 5'CTAGTGCCTGAGACGA-3') covering 720 bp of the NIF coding region. PCR conditions were $94^{\circ} \mathrm{C}$ for $30 \mathrm{~s}, 55^{\circ} \mathrm{C}$ for $1 \mathrm{~min}$, and $72^{\circ} \mathrm{C}$ for $45 \mathrm{~s}$ carried out for 30 cycles.

Northern blots. Lung total RNA (10 $\mu \mathrm{g}$ per sample) was denatured in formamide and formaldehyde at $55^{\circ} \mathrm{C}$ for $15 \mathrm{~min}$ and electrophoresed through formaldehyde-containing agarose gels. Northern blot reagents were purchased from Stratagene (La Jolla, CA). Briefly, RNA was blotted to Duralose-UV membranes (Stratagene) and the membranes were cross-linked, hybridized, and washed as directed by the manufacturer. The cDNA probes were labeled with $\left[\alpha{ }^{-32} \mathrm{P}\right] \mathrm{dCTP}(3,000 \mathrm{Ci} / \mathrm{mM})$ by the random priming method and the membranes were exposed to Kodak autoradiography film (Eastman Kodak Co., Rochester, NY) at $-80^{\circ} \mathrm{C}$ for $6 \mathrm{~h}$.

Histology and immunohistochemistry. Mouse lungs were inflated with $4 \%$ paraformaldehyde in $1 \times \mathrm{PBS}(\mathrm{pH} 7.4)$ and embedded in paraffin. Tissue blocks were sectioned to $5 \mu \mathrm{m}$ thick and mounted onto poly-L-lysine-treated glass slides. The lung tissue was stained with hematoxylin and eosin to identify changes after NIF expression in the intraperitoneal (i.p.) LPS-challenged mice (see below). For immunostaining, serial sections were incubated with blocking buffer ( $1 \%$ goat serum in $1 \times \mathrm{PBS}, \mathrm{pH} 7.4)$ for $1 \mathrm{~h}$ at room temperature. A rabbit anti-NIF polyclonal antibody (1:500) obtained from Dr. Howard Soule was loaded onto sections and incubated overnight at $4^{\circ} \mathrm{C}$. Sections were then incubated with a biotinylated goat anti-rabbit IgG (1:250) in blocking buffer at room temperature for $1 \mathrm{~h}$. Control sections were incubated with preimmune rabbit $\operatorname{IgG}$ and then, in the same manner, with the secondary antibody (biotinylated goat anti-rabbit $\mathrm{IgG}$ ). All sections were incubated with colloidal goldlabeled ExtrAvidin (1:50; Sigma Chemical Co.) for $10 \mathrm{~min}$ at room temperature and counterstained with eosin after rinsing with PBS to detect NIF expression.

LPS challenge. Except where otherwise indicated each mouse received $200 \mu \mathrm{g}$ of LPS (0111:B4; Sigma Chemical Co.) dissolved in 0.5 $\mathrm{ml}$ of PBS ( $\mathrm{pH}$ 7.4) via i.p. injection. Control mice were injected i.p. with an equal volume of PBS. Lung tissue myeloperoxidase (MPO) activity was assayed (see Methods) to determine PMN sequestration at different times after LPS injection (five mice in each group were killed at each time point).

To determine the effects of NIF expression on LPS-induced lung PMN sequestration, 5-10 mice in each group were injected i.v. with PBS, liposomes, or transgene/liposome complexes $48 \mathrm{~h}$ before the LPS challenge. Mice were then injected i.p. with LPS or PBS, and were killed by a ketamine and xylazine overdose at $2 \mathrm{~h}$, and the lungs were removed for MPO activity, gene expression, bronchoalveolar lavage (BAL), vascular permeability, and morphological assessment.

$B A L$ and leukocyte counts. The trachea was cannulated and BAL was performed using $1 \mathrm{ml}$ of PBS. BAL fluid was centrifuged using a cytospin and BAL cells were stained with Diff Quik (Baxter Healthcare, McGaw Park, IL). Differential cell counts were determined by counting 300 cells per slide (29). In some mice $(n=5$ for control and $n=5$ for NIF transgene), LPS $(25 \mu \mathrm{g})$ was instilled into the trachea and BAL was carried out at $2 \mathrm{~h}$ as described above. The circulating leukocyte count was determined by obtaining intracardiac blood.

Lung PMN sequestration. Lungs were dried and homogenized in $0.5 \mathrm{ml}$ of $50 \mathrm{mM}$ PBS (pH 6.0) with $5 \%$ of hexadecyltrimethylammonium bromide (HTAB) and 5 mM EDTA for quantification of PMN uptake by MPO activity (30). The homogenates were sonicated, centrifuged at $4 \times 10^{4} \mathrm{~g}$ for $20 \mathrm{~min}$, and frozen and thawed two times followed by homogenization and centrifugation. The supernatant was mixed in $1: 30(\mathrm{vol} / \mathrm{vol})$ with assay buffer $(0.2 \mathrm{mg} / \mathrm{ml}$ of $o$-dianisidine hydrochloride and $0.0005 \% \mathrm{H}_{2} \mathrm{O}_{2}$ ), and absorbance change was measured at $460 \mathrm{~nm}$ for $5 \mathrm{~min}$. MPO activity based on dry lung weight was calculated as change in absorbance over time. 
${ }^{125}$ I-rNIF binding to mouse PMN. rNIF (obtained from Dr. Howard Soule) was labeled with ${ }^{125} \mathrm{I}$ (Amersham). ${ }^{125} \mathrm{I}$-rNIF was separated from free ${ }^{125} \mathrm{I}$ by passage through a 10DG column (Bio-Rad Laboratories, Hercules, CA) in PBS containing $1 \%$ BSA as buffer. The specific activity of ${ }^{125} \mathrm{I}-\mathrm{rNIF}$ was $\sim 8 \mu \mathrm{Ci} / \mu \mathrm{g}$. Mouse PMN $\left(5 \times 10^{5}\right.$ cells $)$ were incubated with $100 \mathrm{nM}$ of ${ }^{125} \mathrm{I}$-rNIF on ice for 30 min with or without increasing concentrations of unlabeled rNIF. Mouse PMNs were isolated by the Ficoll gradient method and binding of ${ }^{125} \mathrm{I}-\mathrm{rNIF}$ was studied in PMNs challenged with LPS $(10 \mathrm{ng} / \mathrm{ml})$. The PMNs incubated with ${ }^{125}$ I-rNIF were washed with ice cold PBS and $1 \%$ BSA three times, and total cell-associated radioactivity was determined by $\gamma$ counting (Auto-gamma 5000; Packard, Downers Grove, IL). Individual data points were obtained in triplicate to establish the binding of ${ }^{125}$ I-rNIF to PMNs. Competition studies were carried out to determine the effects of anti-CD11a and anti-CD11b mAbs added separately or in combination (PharMingen, San Diego, CA) on the binding of ${ }^{125} \mathrm{I}-\mathrm{rNIF}$ to PMNs.

In vitro mouse PMN adhesion. $8 \mathrm{~h}$ before harvesting PMNs, mice were injected i.p. with $2 \mathrm{ml}$ of $4 \%$ Brewer's thioglycolate broth (Difco Inc., Detroit, MI) (31). We chose this dose to obtain a maximal yield of PMNs. Prior experiments demonstrated that PMN yield was $80 \%$ of the total cells with the remaining amount being monocytes and lymphocytes. PMNs were shown to be viable by trypan blue exclusion. PMNs were harvested by peritoneal injection of 5-10 ml RPMI media to wash the peritoneal cavity and facilitate the removal of PMNs. Harvested cells were centrifuged at 1,000 rpm for $10 \mathrm{~min}$. The total yield was $2 \times 10^{7}$ cells per mouse. We determined the effects of NIF on the adhesion of mouse PMN to immobilized fibrinogen and to cultured human umbilical vein endothelial cells as described by Lo et al. (32).

Pulmonary vascular permeability index and wet/dry lung weight ratio. Mice were challenged with a 400- $\mu$ g LPS i.p. injection $48 \mathrm{~h}$ af- ter i.v. injection of liposome, pCR3/liposome complex, or pCR3-NIF/ liposome complex. $3 \mathrm{~h}$ later, mice were i.v. injected with $1 \mu \mathrm{Ci}$ of ${ }^{125}$ I-labeled albumin and killed $1 \mathrm{~h}$ after the injection of albumin tracer. Normal mice (i.e., those animals not challenged with LPS) were studied in the same way. Radioactivities of both blood and whole lung were counted to measure the pulmonary vascular permeability index (33) given to the ratio of lung counts per gram of dry lung weight-to-blood counts per gram of blood weight. The final wet/ dry lung weight ratios in different groups were calculated to provide a measure of pulmonary edema.

Statistical analysis. Data are presented as mean \pm SEM unless otherwise indicated. Comparisons between experimental groups were made by ANOVA and the Wilcoxon test. $(P<0.05)$.

\section{Results}

In vivo expression of NIF transgene and protein. The NIF gene and the reporter gene encoding CAT were separately constructed into the eukaryotic expression vector, pCR3, to transfer these exogenous genes in mouse lungs by liposomes. Liposomes were prepared and mixed with DNA constructs at a ratio of $1 \mu \mathrm{g}$ of DNA to $8 \mathrm{nmol}$ of liposome molecules (see Methods). The transgene $(50 \mu \mathrm{g})$ was injected i.v. into each CD1 mouse in a total volume of $200 \mu$ l containing $5 \%$ glucose. The organs were removed at $48 \mathrm{~h}$ for gene expression analysis. Fig. 1, $A$ and $B$, indicates the high and relatively selective CAT transgene expression in lungs after the i.v. injection of DNA/liposome complexes.

Lung NIF gene expression was initially determined by RT-PCR (Fig. 2 A). The DNA fragment covering the 720 bp
A

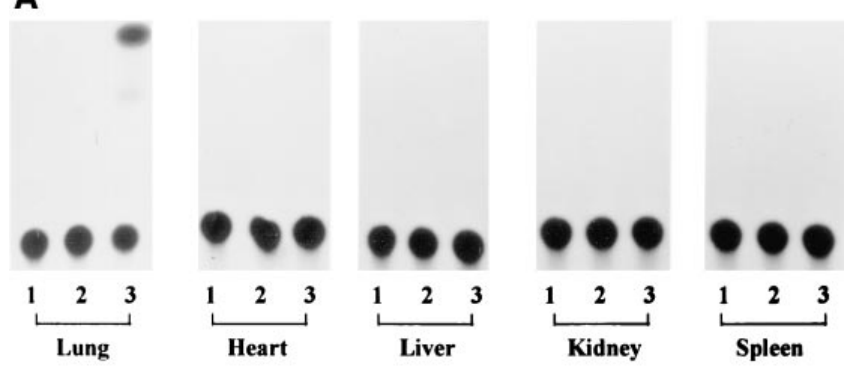

Figure 1. CAT activities in the lung, heart, liver, kidney, and spleen. $(A)$ CAT activity was determined after i.v. injection of either liposomes alone (lane 1 ), wild-type pCR3/liposome complex (lane 2), or pCR3-CAT/liposome complex (lane 3). Figure shows representative data. $(B)$ CAT activities (expressed as percentage of conversion rate of CAT per $100 \mu \mathrm{g}$ of protein in different organs). $n=5$ mice per group (bars indicate mean \pm SEM). *Difference from other groups $(P<0.05)$. 
NIF cDNA coding region was observed only in lungs of mice injected with the pCR3-NIF/liposome complex. This PCR product was not observed in control samples pretreated with DNase I and without reverse transcription, indicating the absence of DNA contamination in RNA samples. We observed, by immunostaining, the presence of NIF protein in pulmonary vascular endothelial cells and a dense staining pattern of the intraluminal leukocytes present in pulmonary microvessels (Fig. 2 B). In contrast, anti-NIFAb did not stain red blood cells (which do not express $\beta_{2}$ integrins) (Fig. 2 B). RT-PCR analysis of circulating leukocytes obtained from mice with a high level of NIF expression in their lungs showed that these cells did not express the NIF gene (Fig. 3). This observation is consistent with release of NIF into the pulmonary microcirculation resulting in its rapid binding to $\operatorname{PMN}(22,23)$. In contrast to the leukocytosis evident after i.v. injection of anti-CD18 mAbs $(5,21)$, NIF expression by gene transfer in lungs did not raise the circulating leukocyte count (Table I).

${ }^{125}$ I-rNIF binds to mouse PMN and NIF prevents PMN adhesion. As the effects of NIF binding to LPS-activated mouse PMN are not known, we first determined the binding of ${ }^{125} \mathrm{I}-$ labeled rNIF to isolated mouse PMN. The binding of ${ }^{125}$ I-rNIF to mouse PMN was specific and saturable (Fig. $4 A$ ). Coincubation of ${ }^{125} \mathrm{I}$-rNIF with a 50 -fold excess of unlabeled rNIF reduced the ${ }^{125}$ I-rNIF binding to PMN by $70 \%$. Both anti-CD $11 \mathrm{a}$ and anti-CD11b mAbs competed with ${ }^{125}$ I-rNIF binding to the LPS-activated PMN; each mAb decreased the binding of ${ }^{125} \mathrm{I}$ NIF by $\sim 40 \%$ (Fig. $4 A$ ). Addition of both $\mathrm{mAbs}$ reduced the binding of ${ }^{125}$ I-NIF to PMN further to the same level $(\sim 70 \%)$ as observed with a 50-fold excess of unlabeled NIF (Fig. $4 A$ ). NIF also prevented the adhesion of mouse PMN to immobilized fibrinogen and to endothelial cells in culture (Fig. $4 B$ ).

In vivo expression of NIF in mouse lungs prevents LPSinduced PMN sequestration and lung vascular injury. All mice became lethargic and developed fur ruffling and diarrhea within 30 min of i.p. injection of $200 \mu \mathrm{g}$ of LPS. $2 \mathrm{~h}$ after LPS injection, the MPO activity in lungs increased 3.5-fold compared to PBS-treated control mice $(P<0.05)$ (Fig. 5). PMN uptake remained high for $12 \mathrm{~h}$, and returned to basal levels at $24 \mathrm{~h}$ after LPS challenge. Airspace PMN infiltration was a prominent feature of the lung pathology of the i.p. LPS-challenged mice (Fig. 6).

Mice were injected i.v. with the pCR3-NIF/liposome construct or control reagents (PBS, liposomes, wild-type pCR3/liposome, or pCR3-CAT/liposome complexes) to study the effects of pulmonary vascular expression of NIF in the i.p. LPS challenge model. Mice received an injection of either PBS or LPS i.p. $48 \mathrm{~h}$ after the injection of constructs (when significant NIF expression was evident), and were killed $2 \mathrm{~h}$ after PBS or LPS injection. The right lung was removed for gene expression analysis and the left lung for MPO activity. Analysis by North-

Table I. Circulating Leukocyte Counts in Mice

\begin{tabular}{ccccc}
\hline & Control & LPS & NIF + pCR3 & LPS + pCR2-NIF \\
\hline $\begin{array}{l}\text { Leukocytes } \\
\left(\text { cells } / \mathrm{mm}^{3}\right)\end{array}$ & $6106 \pm 221 *$ & $1812 \pm 202^{\ddagger}$ & $4810 \pm 362$ & $3735 \pm 239$ \\
\hline
\end{tabular}

$*$ Values are mean \pm SEM $\left(n=4\right.$ per group). ${ }^{\ddagger} P<0.01$ compared to other groups.

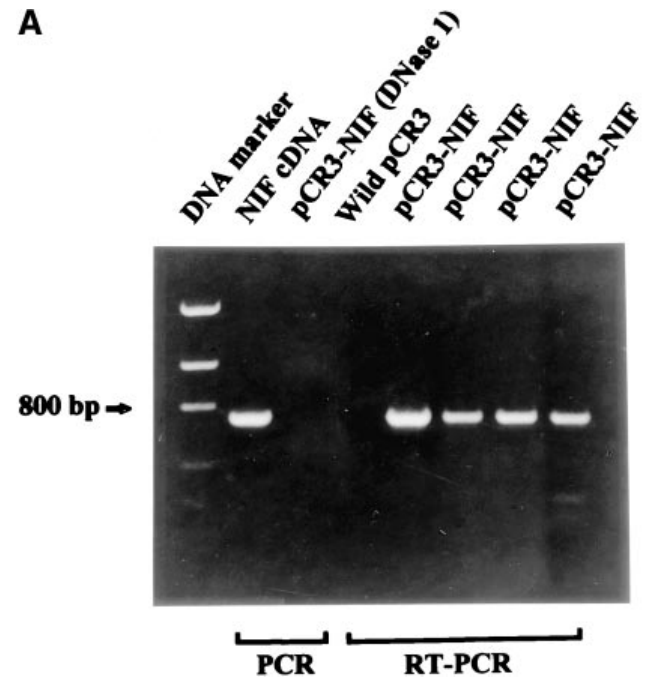

Figure 2. (A) RT-PCR analysis of NIF transgene expression in mouse lungs. From left: lane 1, DNA markers (DNA Mass Ladder; Life Technologies); lane 2, direct PCR from pCR3-NIF (positive control); lane 3, PCR from RNA sample without reverse transcription as negative control (RNA sample was obtained from lung of mouse injected i.v. with the pCR3-NIF/liposome construct); lane 4, RT-PCR from an RNA sample of lung of a mouse injected i.v. with the pCR3/ liposome complex; lanes 5-8, RT-PCR from RNA samples of lungs of four separate mice injected i.v. with the pCR3-NIF/liposome complex. $(B)$ NIF immunostaining of pulmonary microvessel endothelial cells using rabbit polyclonal anti-NIF antibody and secondary biotinylated goat anti-rabbit antibody (bottom). NIF is present in cells of alveolar-capillary membrane and in intraluminal leukocytes $48 \mathrm{~h}$ after injection of the pCR3-NIF liposome construct; red blood cells in vessels (which do not have CD11/CD18 integrins) did not show staining (bottom). Tissue did not react with control preimmune rabbit $\mathrm{IgG}$ and the same secondary antibody as above (top). Magnification, 300.

ern blotting showed NIF transcripts in lungs of both the PBSand LPS-challenged pCR3-NIF injected mice $(n=10)$, but not in the control groups ( $n=5$ for each group) (Fig. 7). The lung MPO activity in LPS-challenged mice expressing NIF was 3.6fold less than in control LPS-challenged mice $(P<0.01)$ (Fig. 8). The lung MPO activity in mice expressing NIF without i.p. LPS challenge was the same as in normal controls. CAT expression did not influence the increase in lung MPO activity induced by LPS (Fig. 8).

Mice became severely leukopenic within $2 \mathrm{~h}$ after i.p. LPS challenge (Table I), which is consistent with increased lung tissue uptake of PMN (Fig. 8). In contrast, the mice expressing NIF in pulmonary microvessels showed a modest decrease in the circulating leukocyte count (Table I), which is consistent with the observed inhibition of lung PMN uptake after i.p. LPS challenge of these animals (Fig. 8).

We also determined, by BAL, the effects of pulmonary vascular NIF expression on PMN migration into the alveolar space after i.p. LPS challenge. LPS challenge did not induce significant PMN infiltration into the alveolar space in mouse lungs expressing NIF, whereas control mice had markedly increased PMN numbers after similar intratracheal (i.t.) LPS challenge (Fig. 9). We compared these results with the effects 

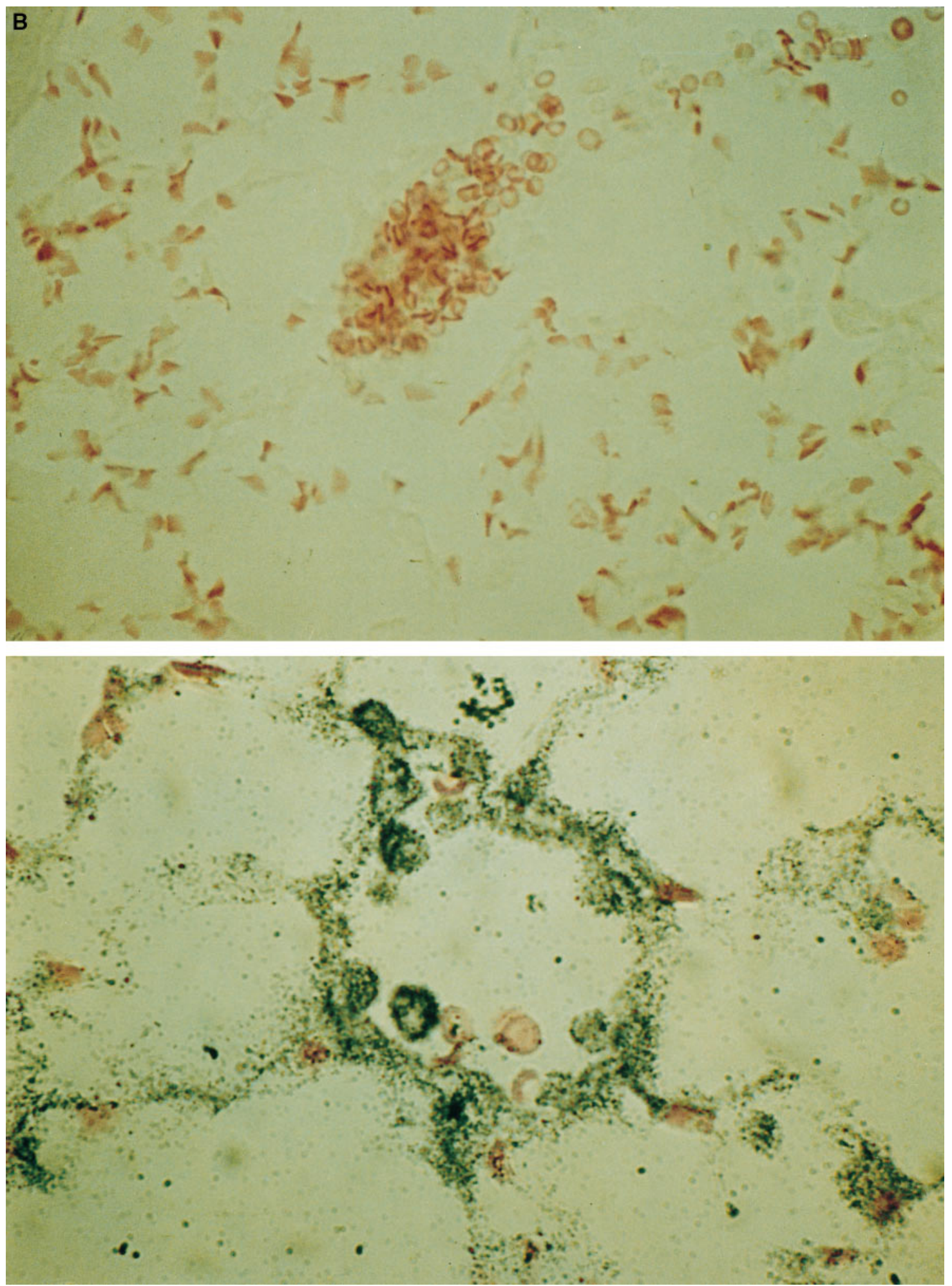

Figure 2 (Continued)

of pulmonary vascular NIF expression on airspace PMN migration induced by i.t. LPS challenge (Fig. 10). NIF expression reduced $\mathrm{PMN}$ migration in this model by $\sim 50 \%$ (Fig. 10) (a significant inhibitory response $[P<0.05]$ but less than the full inhibition of PMN migration observed in the NIF transgenic mice after i.p. LPS challenge [Fig. 9]).
The mice expressing NIF in their lungs, when challenged i.p., had exudate-free alveolar spaces, whereas lungs of control mice challenged i.p. with LPS showed prominent alveolar exudate in association with marked PMN infiltration (Fig. 6). Lung vascular permeability to albumin did not increase significantly in the NIF-expressing mice challenged with LPS, 


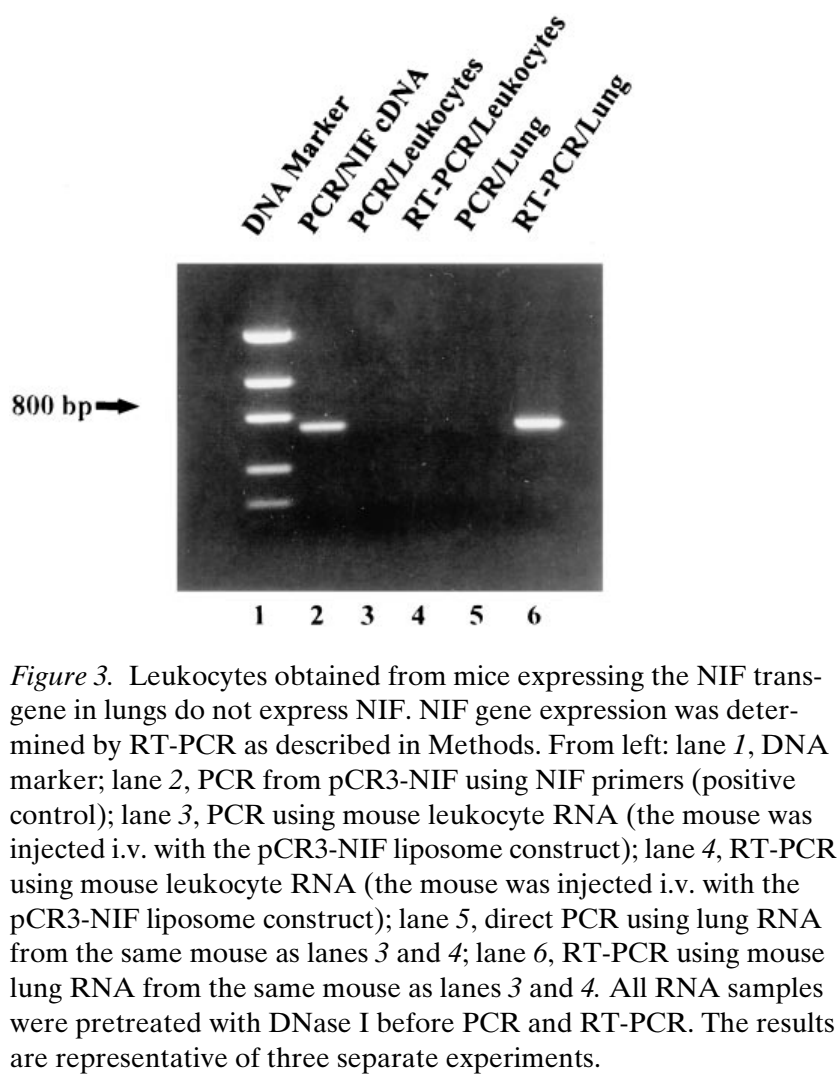

whereas permeability increased two- to threefold in the control groups of mice (Fig. 11), indicating that NIF expression prevented the LPS-induced lung vascular injury. NIF expression also prevented the LPS-induced pulmonary edema as measured by the increase in the lung wet-to-dry weight ratio (Table II).

\section{Discussion}

LPS liberated from the outer membrane of gram-negative bacteria triggers PMNs to synthesize and release a cascade of inflammatory mediators that ultimately can lead to lung injury and multiple organ failure $(1,15,34)$. LPS induces the expression of ICAM-1 and E-selectin on the endothelial cell surface and CD11/CD18 integrins on the PMN plasma membrane, which, through a series of binding interactions, mediates the adhesion of PMNs to the vascular endothelial monolayer and their migration across the endothelial barrier $(5,9,10,11,35)$.

Table II. Expression of NIF Prevents LPS-induced Increase in Wet/Dry Lung Weight Ratio

\begin{tabular}{lccccc}
\hline & Control & LPS & $\begin{array}{c}\text { LPS }+ \\
\text { liposome }\end{array}$ & $\begin{array}{c}\text { LPS }+ \\
\text { pCR3 }\end{array}$ & $\begin{array}{c}\text { LPS }+ \\
\text { pCR3-NIF }\end{array}$ \\
\hline$n$ & 4 & 5 & 5 & 5 & 5 \\
$\begin{array}{l}\text { Wet/dry ratio } \\
(\text { Mean } \pm \text { SEM) })\end{array}$ & $4.7 \pm 0.1$ & $5.1 \pm 0.1^{*}$ & $5.3 \pm 0.1^{\ddagger}$ & $5.3 \pm 0.1^{\ddagger}$ & $4.7 \pm 0.1$
\end{tabular}

*Values are mean \pm SEM. ${ }^{*} P<0.01$ compared with control group.
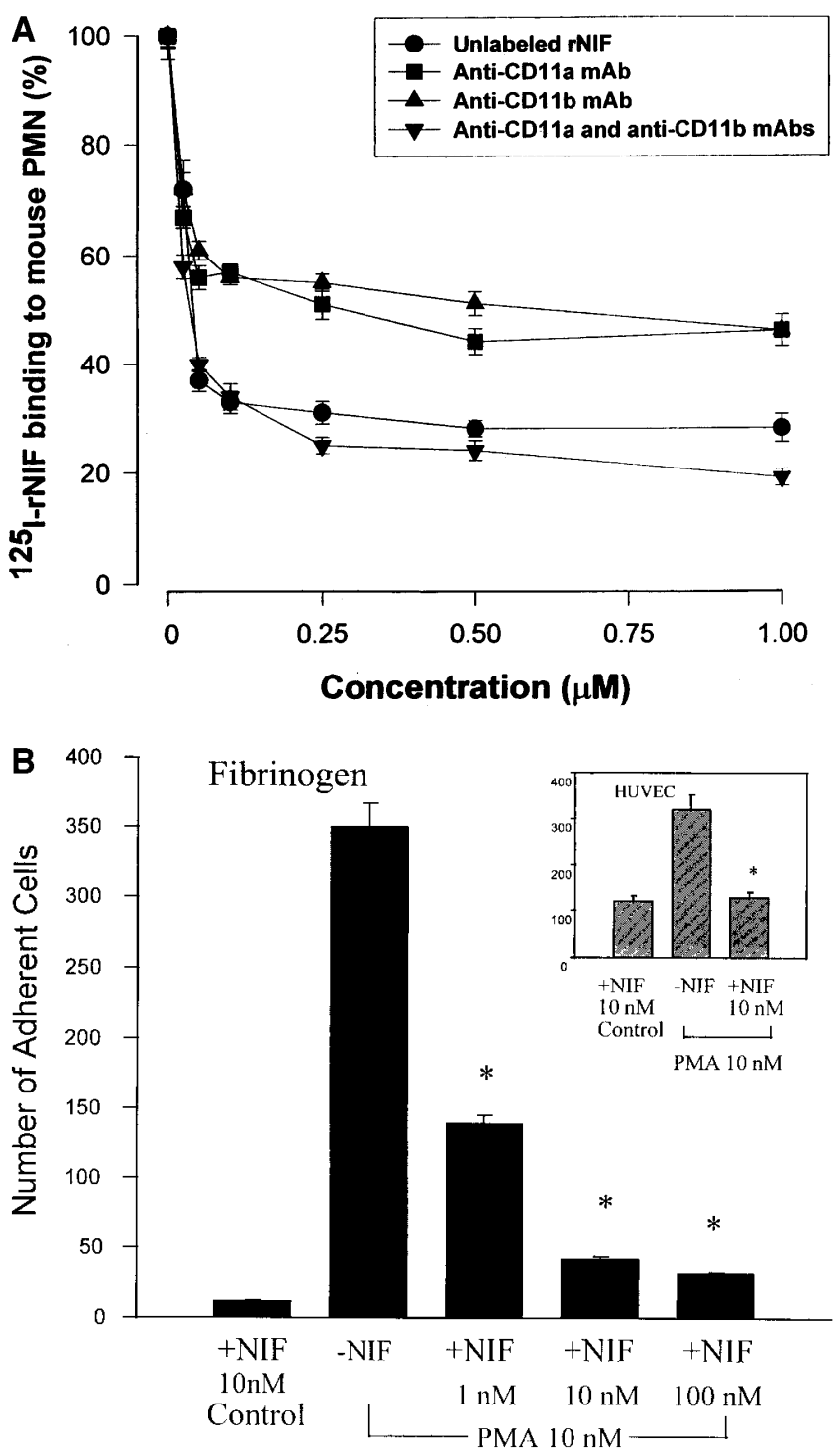

Figure 4. $(A)$ Specific binding of ${ }^{125} \mathrm{I}-\mathrm{rNIF}$ to mouse PMN. Mouse PMNs $\left(5 \times 10^{5}\right)$ activated with LPS $(25 \mathrm{ng} / \mathrm{ml})$ were incubated with ${ }^{125}$ I-rNIF in the absence or presence of unlabeled NIF, anti-mouse $\mathrm{CD} 11 \mathrm{a}$ mAb, anti-mouse CD11b mAb, or both mAbs. Addition of increasing concentrations of unlabeled NIF reduced ${ }^{125}$ I-NIF binding by $\sim 70 \%$. Each $\mathrm{mAb}$ reduced ${ }^{125} \mathrm{I}-\mathrm{NIF}$ binding to mouse PMN $\sim 40 \%$, whereas the reduction with both $\mathrm{mAbs}$ was $\sim 70 \%$. Data are shown as mean \pm SEM of three separate experiments for each concentration. ( $B)$ Mouse PMN adhesion to immobilized fibrinogen and human umbilical vein endothelial cells (HUVECs). Human fibrinogen was immobilized onto glass slides using HSA $(1 \mathrm{mg} / \mathrm{ml})$. NIF was added to the well before the adhesion assay was carried out for 10 min at $37^{\circ} \mathrm{C}$ as described previously (32). Mouse PMN adhered to the fibrinogen-coated surface after addition of phorbol 12-myristate 13acetate (PMA; Sigma Chemical Co.), and NIF caused dose-dependent inhibition of PMN binding to fibrinogen. NIF also inhibited the PMA-activated adhesion of mouse PMNs to HUVECs. Data in both groups are shown as means \pm SEM of three separate experiments in each group. *Difference from the untreated control group ( $-\mathrm{NIF})$ $(P<0.05)$. 


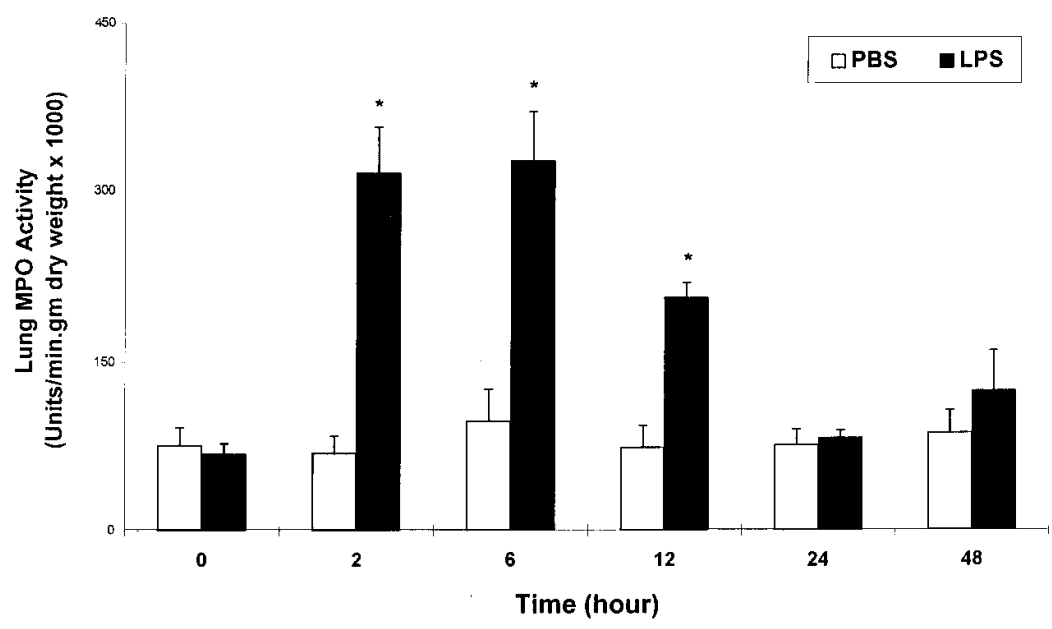

Figure 5. Lung PMN sequestration after i.p. LPS challenge. Mice received $200 \mu \mathrm{g}$ of LPS (i.p.) in $0.5 \mathrm{ml}$ of PBS (black bars) or $0.5 \mathrm{ml}$ of PBS in control group (white bars). MPO activities are shown at different time points after LPS challenge. Bars indicate mean \pm SEM. $* P<0.05$ from control.
In vitro studies showed that the stable adhesion of PMNs resulting from binding of CD11a/CD18 and CD11b/CD18 integrins to ICAM-1 and ICAM-2 expressed on the endothelial cell membrane regulates the transendothelial migration of PMNs $(4,35)$. Expression of CD11a/CD18 and CD11b/CD18 $\beta_{2}$ integrins on PMNs mediates many of the proinflammatory functions of PMNs $(5,11,35-37)$. In vitro studies showed that either anti-CD11a or anti-CD11b mAbs reduced PMN adhesion to endothelial cells by $\sim 50 \%$, whereas these mAbs in combination or mAbs directed against the common $\beta$ subunit (CD18) fully prevented the PMN adhesion response $(5,32)$. Infusion of anti-CD18 mAbs also inhibited lung PMN sequestration in animal models $(5,16)$. However, the specific function of $\beta_{2}$ integrin family members is unclear since mice made genetically deficient in CD11b did not show reduced PMN emigration across the endothelial barrier $(11,19)$.

In this study, we transferred the NIF gene, a recently cloned $\beta_{2}$ integrin antagonist isolated from the canine hookworm $(21,22)$, to study the function of $\beta_{2}$ integrins in regulating LPS-induced PMN trafficking in lungs and in the mechanism of lung vascular injury. We used cationic liposomes injected i.v. to express the NIF transgene and studied effects of in vivo NIF expression in an i.p. LPS challenge model that elicited lung tissue PMN sequestration and increased lung vascular permeability. We used i.v. injected cationic liposomes because this approach has been effective in inducing transient gene transfer in lungs $(27,38,39)$. We showed that i.v. injection of CAT/liposome and NIF/liposome transgene constructs resulted in a lung-selective expression of these transgenes. NIF expression induced by this method was confined to pulmonary microvessel wall cells including the microvessel endothelial cells, consistent with recent evidence of endothelial cell uptake of cationic liposome-DNA complexes in mice (40). The selectivity of gene transfer in pulmonary microvessel cells may be related to factors such as the large pulmonary vascular surface area, delivery of the entire cardiac output to pulmonary circuit, and electrostatic charge-dependent binding of cationic liposomes to vascular endothelial cells (27). We also observed significant NIF immunostaining on membranes of leukocytes present in the lumen of pulmonary microvessels, perhaps reflecting the high affinity NIF binding to PMN $\beta_{2}$ integrins (22, 23). The NIF gene was not expressed in circulating leukocytes of these mice, suggesting that positive NIF immunostaining of PMN is the result of the released NIF binding to leukocytes in transit through the pulmonary circuit.

In establishing the model of LPS-induced lung PMN infiltration, we showed that i.p. injection of LPS in mice resulted in a time-dependent increase in lung tissue MPO activity, which peaked $2 \mathrm{~h}$ after LPS challenge, and persisted for $12 \mathrm{~h}$. Lung PMN sequestration in these mice was consistent with the severe leukopenia seen within $2 \mathrm{~h}$ after LPS challenge. We also showed an increased number of PMN recovered by BAL at $2 \mathrm{~h}$ after LPS challenge indicating the emigration of PMN into airspaces. Histological examination revealed PMN infiltration into both the interstitium and airspaces. These mice also showed alveolar exudate consistent with evidence of lung injury as described in CD1 mice challenged with LPS (41). The pulmonary vascular NIF expression in mice prevented LPSinduced leukopenia and lung PMN sequestration as well as the emigration of PMN into the airspaces. The in vivo NIF expression in lungs also prevented the LPS-induced increase in lung vascular permeability and edema formation.

The basis of the protective effects of NIF expression may be related to the binding of NIF to PMN $\beta_{2}$ integrins, and the resultant inhibition of PMN adhesion. We showed that NIF was capable of fully inhibiting adhesion of mouse PMN. We also showed that LPS induced specific and saturable binding of ${ }^{125}$ I-labeled rNIF to mouse PMN and that anti-CD11a or antiCD11b mAbs competed for ${ }^{125}$ I-NIF binding to these PMN. Addition of both mAbs reduced ${ }^{125}$ I-NIF binding to the same level $(\sim 70 \%)$ as the excess unlabeled NIF. These results are consistent with our findings using phorbol ester-activated PMN and JY lymphoblastoid cells (which only express the CD11a/CD18 integrin) that NIF can bind to both CD11a and CD11b integrins on activated PMN (Malik, A.B., and S.K. Lo, unpublished observation). Therefore, a tenable explanation for the inhibition of PMN uptake in lungs expressing NIF may be that NIF binds to CD11a/CD18 and CD11b/CD18 integrins, thus, inactivating both integrins.

PMN migration into airspaces after the i.t. LPS instillation was inhibited only by $\sim 50 \%$, whereas pulmonary vascular NIF expression prevented the migration of PMN into airspaces after i.p. LPS challenge. This finding suggests that septicemia induces PMN migration across the microvessel and air- 


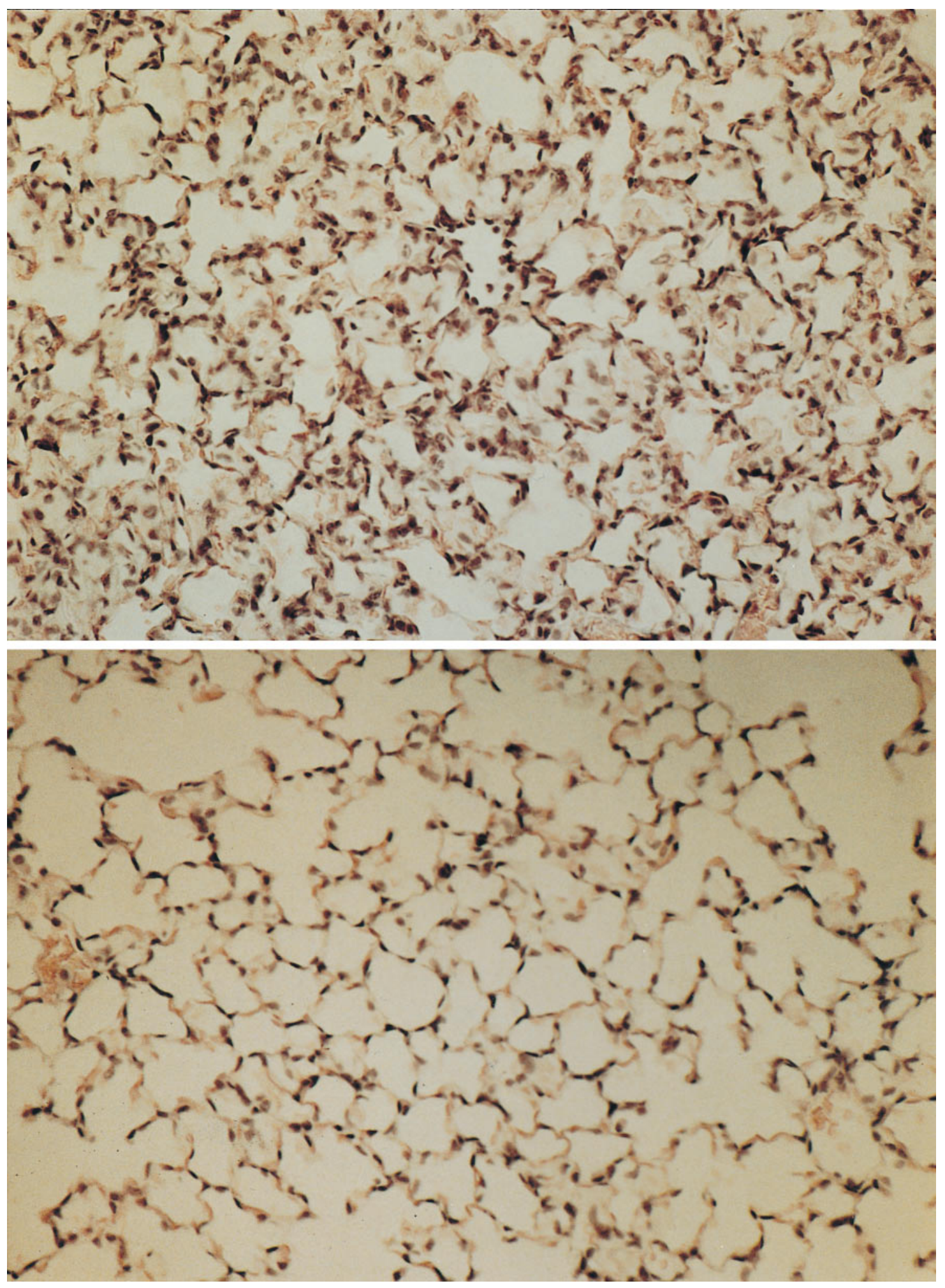

Figure 6. Absence of alveolar PMN infiltration and exudation after NIF expression in lungs of mice challenged with i.p. LPS. Hematoxylin- and eosin-stained sections from mouse lung expressing NIF and challenged with LPS (bottom) were compared to control mouse injected i.v. with the liposome construct and then challenged with LPS (top). Magnification, 500.

way epithelial barriers via activation of $\beta_{2}$ integrins. In contrast, airway gram-negative infection may induce PMN migration into airspaces by both $\beta_{2}$ integrin-dependent and -independent mechanisms. Airway LPS may result in the release of chemokines (e.g., IL-8 [5] and macrophage inflammatory protein-1 [41]) capable of directing PMN into airspaces independent of CD18 integrins.

We evaluated the possibility that liposome injection may 
A.

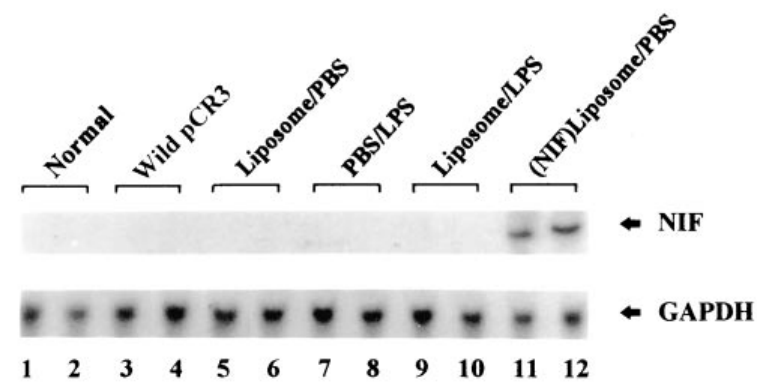

B.

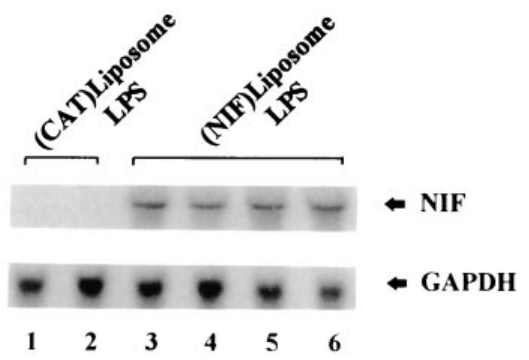

Figure 7. NIF gene expression in lungs of mice injected i.v. with pCR3-NIF as determined by Northern blotting. $(A)$ Control groups of animals were injected with: no vehicle (lanes 1 and 2); the pCR3/liposome complex (lanes 3 and 4); liposomes/PBS (lanes 5 and 6 ); PBS (lanes 7 and 8); liposomes/LPS (lanes 9 and 10); or the pCR3-NIF/liposome complex (lanes 11 and 12 ) for $48 \mathrm{~h}$; and then challenged with either PBS (lanes 5, 6, 11, and 12) or LPS (lanes 7-10) for $2 \mathrm{~h}$ before killing. Note that NIF expression was only observed in lungs of the two animals injected i.v. with NIF/liposome complex constructs. $(B)$ Mice were injected i.v. with the CAT gene construct (lanes 1 and 2) or the NIF gene construct (lanes 3-6) for $48 \mathrm{~h}$, and then challenged with LPS for $2 \mathrm{~h}$. Note that all four mice injected with the pCR3-NIF/ liposome complex expressed NIF mRNA. GAPDH mRNA expression did not change in any group.

have independently interfered with PMN uptake response and that this could account for our results. We showed that liposome injection alone did not induce or prevent the increase in lung PMN uptake. Moreover, injection of the CAT construct

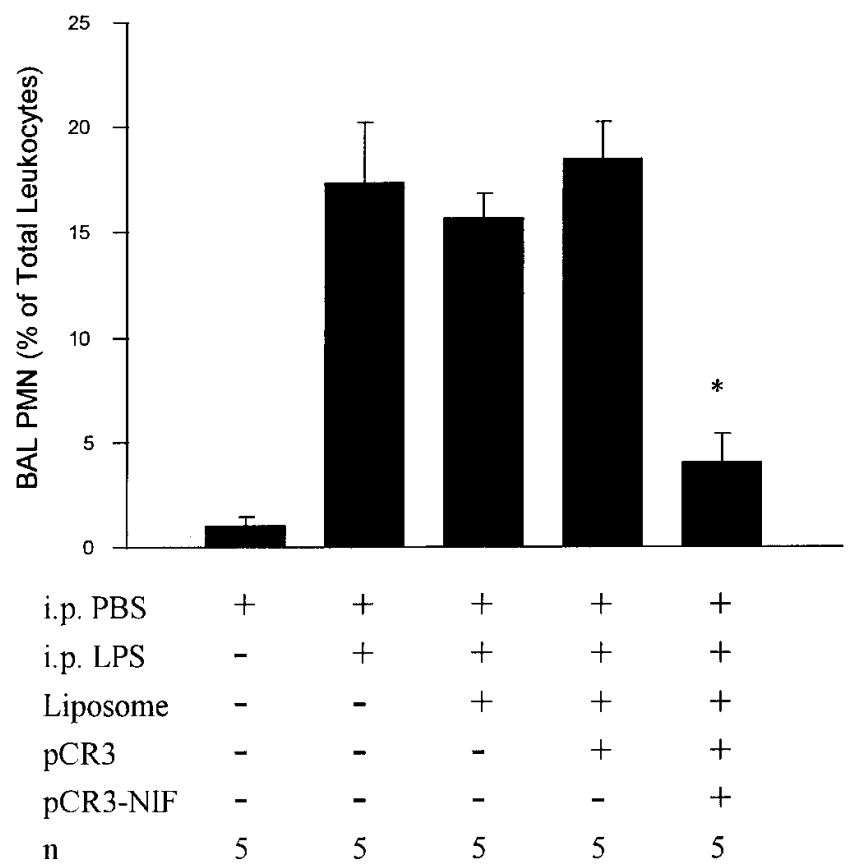

Figure 9. Migration of PMN into airspace determined by $B A L$ in mice challenged with i.p. LPS. Normal mice injected i.p. with PBS and mice injected i.p. with LPS were used as controls. The other three groups of mice were injected with liposome, liposome/pCR3, and liposome/pCR3-NIF, respectively, $48 \mathrm{~h}$ before LPS challenge. PMN migration into lung airspace was observed after i.p. LPS (400 $\mu \mathrm{g}$ per mouse) challenge NIF expression reduced PMN infiltration into the mouse lung airspace. Bars indicate mean \pm SEM. *Difference from control group $(P<0.05)$.

with the similarly prepared liposomes resulted in lung expression of CAT, but failed to prevent the LPS-induced lung PMN uptake. NIF expression in lungs also did not reduce the basal level of PMN sequestration, a finding in agreement with the lack of involvement of CD11/CD18 integrins in regulating the normal marginated pool of PMN in the pulmonary vascular bed (28).

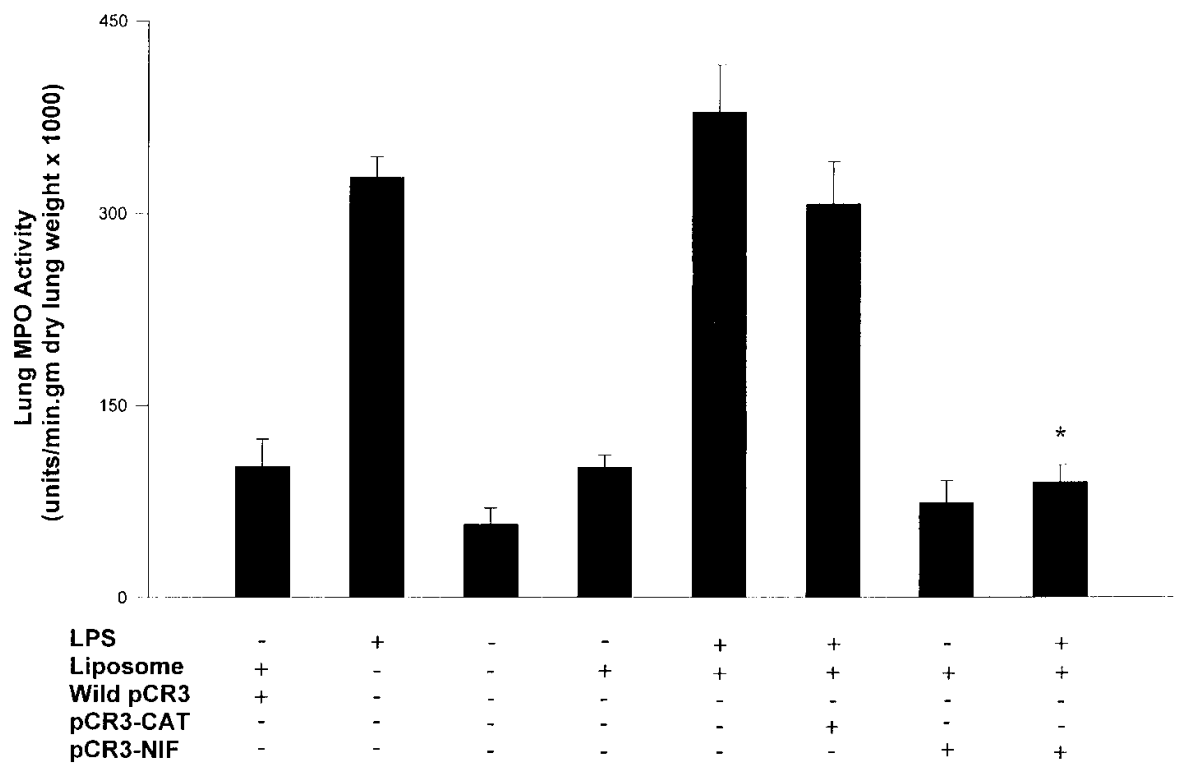

Figure 8. Effects of NIF expression on LPS-induced lung PMN sequestration. Mice were injected i.v. with $\mathrm{pCR} 3-\mathrm{NIF} /$ liposome complex constructs $(n=10)$ or control interventions $(n=5$ for each group); i.e., PBS, liposomes alone, pCR3/ liposome complex, or pCR3-CAT/liposome complex for $48 \mathrm{~h}$. Mice were then challenged with LPS or PBS and at $2 \mathrm{~h}$, MPO activities were determined. LPS challenge resulted in three- to fourfold increases in MPO activity except in the presence of NIF expression. Bars indicate mean \pm SEM. *Difference from LPS-challenged control $(P<0.05)$. 


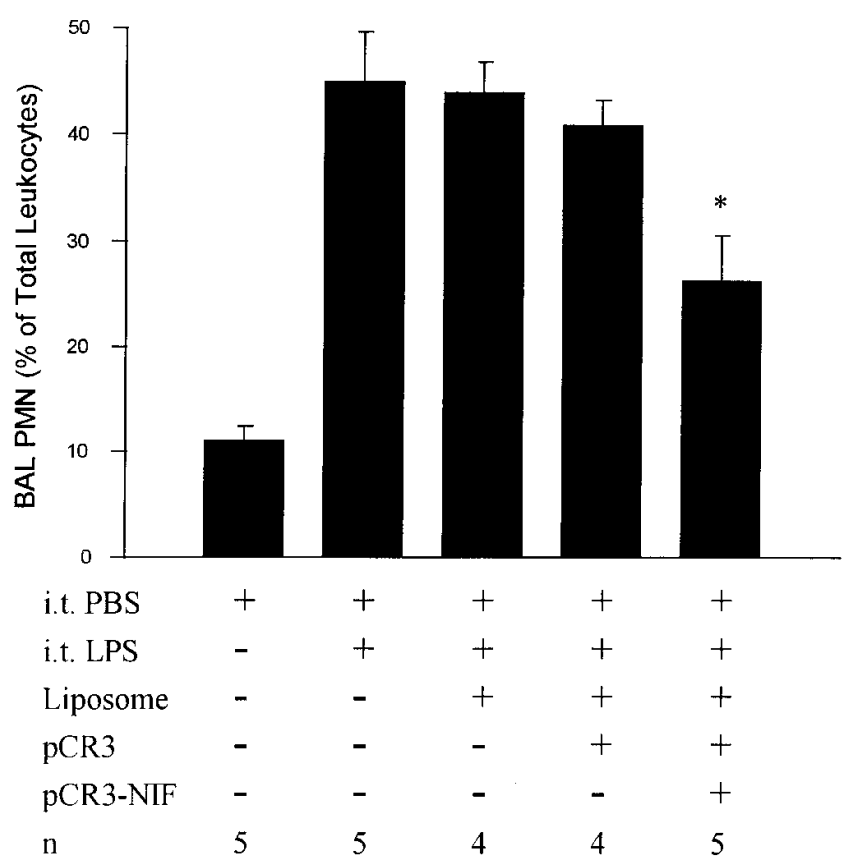

Figure 10. Migration of PMN into lung airspace determined by BAL in mice challenged with LPS via i.t. instillation. Normal mice instilled i.t. with PBS and LPS were used as controls. The other three groups of mice were injected with liposome, liposome/cCR3, or liposome/ pCR3-NIF, respectively, $48 \mathrm{~h}$ before LPS challenge. PMN migration into lung airspace was observed after i.t. LPS ( $25 \mu \mathrm{g}$ per mouse) challenge. NIF expression reduced PMN infiltration into mouse lung airspace by $\sim 50 \%$ from the maximum response in the control LPSchallenged mice. Bars indicate mean \pm SEM. *Difference from control group $(P<0.05)$.

We have shown previously that NIF gene transfer in cultured endothelial cells elicits NIF release into the culture conditioned medium (Malik, A.B., unpublished observation); however, we were not able to detect circulating NIF in mice (data not shown), which may reflect NIF's binding to leukocytes (22, $23)$. In this regard, the localized release of NIF into the microcirculation by endothelial cells and other vessel wall cells and its rapid binding to $\beta_{2}$ integrins on LPS-activated PMN may have the advantage of not interfering with the immune hostdefense function of PMN. In contrast, the i.v. injection of antiCD18 mAbs impairs PMN function and worsens infection (3, $5,20,34)$. The finding that NIF expression did not induce the leukocytosis that is characteristically observed after injection of anti-CD18 mAbs and in patients with leukocyte adhesion deficiency (LAD) (3) also suggests that the release of NIF by the transduced cells is a localized event. Therefore, in vivo transfer of the NIF gene can provide a means of continuously delivering NIF into the microcirculatory compartment to prevent PMN adhesion and migration of PMN across the vessel wall. Further specificity in NIF delivery may be effected through endothelial cell type-specific and antibiotic-inducible promoters.

In summary, we report that transfer of the NIF gene encodes the $41-\mathrm{kD}$ antiadhesive protein in pulmonary microvessel wall cells of mice. NIF expression prevented LPS-induced lung PMN uptake and PMN migration into airspaces, and the

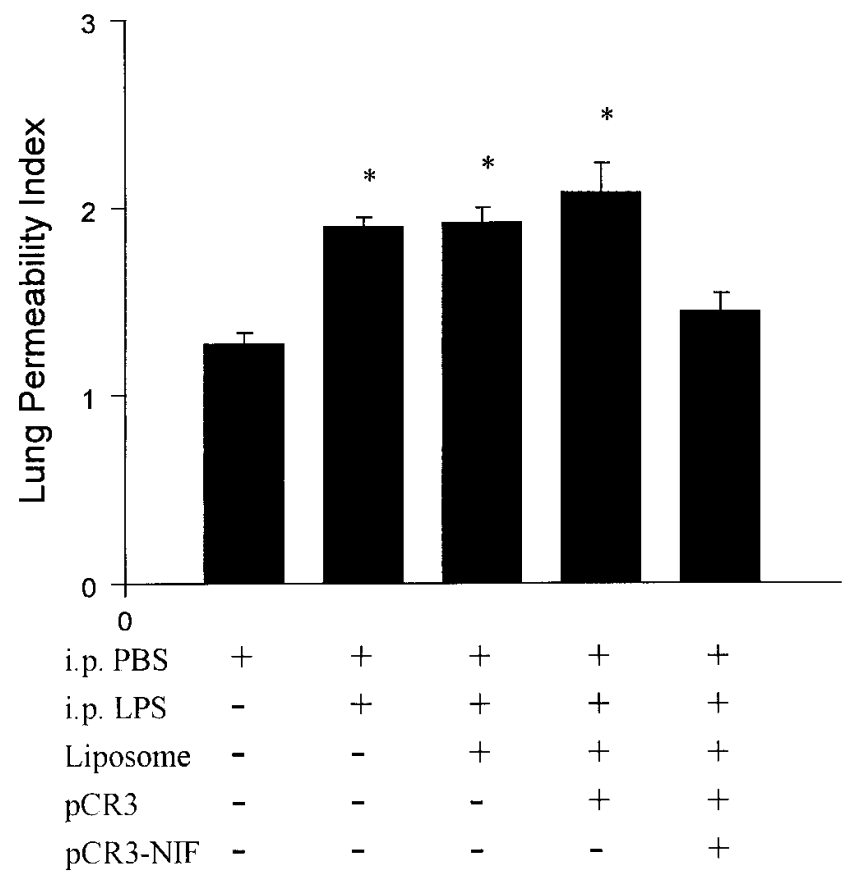

Figure 11. Pulmonary vascular permeability index was determined using ${ }^{125} \mathrm{I}$-albumin as the tracer (see Methods). Expression of NIF prevented the increase in the pulmonary vascular permeability after LPS (400 $\mu$ i.p.) challenge of mice, while permeability increased significantly in the control groups (LPS alone, liposome/LPS, and pCR3/ liposome/LPS). Bars indicate mean \pm SEM. *Significant difference from the normal control group $(n=5$ in each group; $P<0.01)$.

associated lung vascular injury. We conclude that in vivo pulmonary vascular expression of NIF, a specific $\beta_{2}$ integrin-binding protein, is a potentially useful gene transfer strategy in modulating the infiltration of PMN across the alveolar-capillary epithelial barriers and in preventing lung endothelial injury.

\section{Acknowledgments}

We thank Dr. Wei Song for help in setting up the immunocytochemistry experiments, Ms. Rosemarie Mathura for the adhesion assay, and Drs. Philip Sass and Stephen Vogel for valuable discussion. Magnus Bergenfeldt was on sabbatical leave from University of Malmö, Sweden.

This work was supported in part by the American Physiological Society, by National Institutes of Health grants HL-45638, HL-27016, and HL-46350, and by Grant-in-Aid (Chicago Chapter of American Heart Association).

\section{References}

1. Brigham, K.L., and B. Meyrick. 1986. Endotoxin and lung injury. Am. Rev. Respir. Dis. 133:913-927.

2. Tate, R.M., and J.E. Repine. 1983. Neutrophils and the adult respiratory distress syndrome. Am. Rev. Respir. Dis. 128:552-559.

3. Harlan, J.M. 1987. Neutrophil-mediated vascular injury. Acta Med. Scand. Suppl. 715:123-129.

4. Xie, J., R. Li, P. Kotovuori, C. Vermont-Desroches, J. Wijdense, M.A. Arnaout, P. Nortamo, and C.G. Gahmberg. 1995. Intercellular adhesion molecule-2 (CD102) binds to the leukocyte integrin CD11b/CD18 through the A domain. J. Immunol. 155:3619-3628.

5. Malik, A.B., and S.K. Lo. 1996. Vascular endothelial adhesion molecules 
and tissue inflammation. Pharmacol. Rev. 48:213-229.

6. Anderson, D.C., and T.A. Springer. 1987. Leukocyte adhesion deficiency: an inherited defect in the Mac-1, LFA-1, and p150,95 glycoproteins. Ann. Rev. Med. 38:175-194.

7. Arnaout, M.A., S.K. Gupta, M.W. Pierce, and D.G. Tenen. 1988. Amino acid sequence of the alpha subunit of human leukocyte adhesion receptor Mo1 (complement receptor type 3). J. Cell Biol. 106:2153-2158.

8. Arnaout, M.A. 1990. Structure and function of the leukocyte adhesion molecules CD11/CD18. Blood. 75:1037-1050.

9. Furie, M.B., M.C.A. Tancinco, and C.W. Smith. 1991. Monoclonal antibodies to leukocyte integrins CD11a/CD18 and CD11b/CD18 or intercellular adhesion molecule-1 inhibit chemoattractant-stimulated neutrophil transendothelial migration in vitro. Blood. 78:2089-2097.

10. Graf, J.M., C.W. Smith, and M.M. Mariscalco. 1996. Contribution of LFA-1 and Mac-1 to CD18-dependent neutrophil emigration in a neonatal rabbit model. J. Appl. Physiol. 80:1984-1992.

11. Lu, H., C.W. Smith, J. Perrard, D. Bullard, L. Tang, S.B. Shappell, M.L. Entman, A.L. Beaudet, and C.M. Ballantyne. 1997. LFA is sufficient in mediating neutrophil emigration in Mac-1-deficient mice. J. Clin. Invest. 99:13401350 .

12. Lee, J.O., P. Rieu, M.A. Arnaout, and R. Liddington. 1995. Crystal structure of the A domain from the alpha-subunit of integrin CR3 (CD11b/ CD18). Cell. 80:631-638.

13. Zhou, L., D.H.S. Lee, J. Plescia, C.Y. Lau, and D.C. Liddington. 1994 Differential ligand binding specificities of recombinant CD11b/CD18 integrin I-domain. J. Biol. Chem. 269:17075-17079.

14. Rothlein, R., M.L. Dustin, S.D. Marlin, and T.A. Springer. 1986. A human intercellular adhesion molecule (ICAM-1) distinct from LFA-1. J. Immunol. 137:1270-1274.

15. Vedder, N.B., R.K. Winn, C.L. Rice, and J.M. Harlan. 1989. Neutrophilmediated vascular injury in shock and multiple organ failure. Prog. Clin. Biol. Res. 299:181-191.

16. Morisaki, T., T. Goya, H. Toh, K. Nishihara, and M. Torisu. 1991. The anti Mac-1 monoclonal antibody inhibits neutrophil sequestration in lung and liver in a septic murine model. Clin. Immunol. Immunopathol. 61:365-375.

17. Tang, W.W., E.S. Yi, D.G. Remick, A. Wittwer, S. Yin, M. Qi, and T.R. Ulich. 1995. Intratracheal injection of endotoxin and cytokines. IX. Contribution of CD11a/ICAM-1 to neutrophil emigration. Am. J. Physiol. 269:L653L659.

18. Kumasaka, T., W.M. Quinlan, N.A. Doyle, T.P. Condon, and C. Doerschuk. 1997. Role of the intercellular adhesion molecule-1 (ICAM-1) in endotoxin-induced pneumonia evaluated using ICAM-1 antisense oligonucleotides, anti-ICAM-1 monoclonal antibodies, and ICAM-1 mutant mice. J. Clin. Invest. 10:2362-2369.

19. Lu, H., B.J. Hughes, J. Smolen, C.M. Ballantyne, L. Tang, A.L. Beaudet, and C.W. Smith. 1997. Role of Mac-1 (CD1b/CD18) in neutrophil functions in vivo. FASEB (Fed. Am. Soc. Exp. Biol.) J. 11:1963a. (Abstr.)

20. Eichacker, P.Q., W.D. Hoffman, A. Farese, R.L. Danner, A.F. Suffredini, Y. Waisman, S.M. Banks, T. Mougins, L. Wilson, R. Rothlein, et al. 1993. Leukocyte CD18 monoclonal antibody worsens endotoxemia and cardiovascular injury in canines with septic shock. J. Appl. Physiol. 74:1885-1892.

21. McCandless, B.K., R.P. Kaufman, Jr., J.A. Cooper, P.H. Neumann, and A.B. Malik. 1994. Mediation of lung neutrophil uptake after endotoxin by CD18-integrin-dependent and-independent mechanisms. Am. J. Physiol. 266: H1451-H1456.

22. Moyle, M., D.L. Foster, D.E. McGrath, S.M. Brown, Y. Laroche, J.D. Meutter, P. Stanssens, C.A. Bogowitz, V.A. Fried, J.A. Ely, et al. 1994. A hookworm glycoprotein that inhibits neutrophil function is a ligand of the integrin CD11b/CD18. J. Biol. Chem. 269:10008-10015.
23. Muchowski, P.J., L. Zhang, E.R. Chang, H.R. Soule, E.F. Plow, and M. Moyle. 1994. Functional interaction between the integrin antagonist neutrophil inhibitory factor and the I domain of CD11b/CD18. J. Biol. Chem. 269:26419_ 26423

24. Rieu, P., T. Ueda, I. Haruta, C.P. Sharma, and M.A. Arnaout. 1994. The A-domain of $\beta_{2}$ integrin CR3 (CD11b/CD18) is a receptor for the hookwormderived neutrophil adhesion inhibitor NIF. J. Cell Biol. 127:2081-2091.

25. Barnard, J.W., M.G. Biro, S.K. Lo, S. Ohno, M.A. Carozza, M. Moyle, H.R. Soule, and A.B. Malik. 1995. Neutrophil inhibitory factor prevents neutrophil-dependent lung injury. J. Immunol. 155:4876-4881.

26. Liu, Y., D. Liggitt, W. Zhong, G. Tu, K. Gaensler, and R. Debs. 1995 Cationic liposome-mediated intravenous gene delivery. J. Biol. Chem. 270: 24864-24870.

27. Gao, X., and L. Huang. 1995. Cationic liposome mediated gene transfer. Gene Ther. 2:710-722.

28. Ausubel, F.M., R. Brent, R.E. Kingston, D.D. Moore, J.G. Seidman, J.L. Smith, and K. Struhl. 1995. Current Protocols in Molecular Biology. John Wiley and Sons, New York. 975-976.

29. Saltini, C., A.J. Hance, V.J. Ferrans, F. Basset, P.B. Bitterman, and R.G. Crystal. 1984. Accurate quantification of cells recovered by bronchoalveolar lavage. Am. Rev. Respir. Dis. 130:650-658.

30. Krawisz, J.E., P. Sharon, and W.F. Stenson. 1984. Quantitative assay for acute intestinal inflammation based on myeloperoxidase activity. Gastroenter ology. 87:1344-1350.

31. Jin, F., C. Nathan, D. Radzioch, and A. Ding. 1997. Secretory leukocyte protease inhibitor: a macrophage product induced by and antagonistic to bacterial lipopolysaccharide. Cell. 88:417-426.

32. Lo, S.K., G.A. Van Seventer, S.M. Levin, and S.D. Wright. 1989. Two leukocyte receptors (CD11a/CD18 and CD11b/CD18) mediate transient adhesion to endothelium by binding to different ligands. J. Immunol. 143:3325-3329.

33. Green, T.P., D.E. Johnson, T.P. Marchessault, and C.W. Gatto. 1988 Transvascular flux and tissue accrual of Evans blue: effects of endotoxin and histamine. J. Lab. Clin. Med. 111:173-183.

34. Glauser, M.P., G. Zanetti, J.-D. Baumgartner, and J. Cohen. 1991. Septic shock: pathogenesis. Lancet. 338:732-739.

35. Springer, T.A. 1994. Traffic signals for lymphocyte recirculation and leukocyte emigration: the multistep paradigm. Cell. 76:301-314.

36. Diamond, M.S., J. Garcia-Aguilar, J.K. Bickford, A.L. Corbi, and T.A. Springer. 1993. The I domain is a major recognition site on the leukocyte integrin Mac-1 (CD11b/CD18) for four distinct adhesion ligands. J. Cell Biol. 120: 1031-1043.

37. Miotla, J.M., T.J. Williams, P.G. Hellewell, and P.K. Jeffery. 1996. A role for the $\beta_{2}$ integrin CD11b in mediating experimental lung injury in mice. Am. J. Respir. Cell Mol. Biol. 14:363-373.

38. Curiel, D.T., J.M. Pilewski, and S.M. Albelda. 1996. Gene therapy approaches for inherited and acquired lung diseases. Am. J. Respir. Cell Mol. Biol. 14:1-18.

39. Muller, D.W., D. Gordon, H. San, Z. Yang, and E.G. Nabel. 1994. Catheter-mediated pulmonary vascular gene transfer and expression. Circ. Res. 75: 1039-1049.

40. McLean, J.W., E.A. Fox, P. Baluk, P.B. Bolton, A. Haskell, R. Pearlman, G. Thurston, E.Y. Umemoto, and D.M. McDonald. 1997. Organ-specific endothelial cell uptake of cationic liposome-DNA complexes in mice. Am. J. Physiol. 273:H387-H404.

41. Standiford, T.J., S.L. Kunkel, N.W. Lukacs, M.J. Greenberger, J.M. Danforth, R.G. Kunkel, and R.M. Streiter. 1995. Macrophage inflammatory protein-1 mediates lung leukocyte recruitment, lung capillary leak, and early mortality in murine endotoxemia. J. Immunol. 155:1515-1524. 